\title{
The Impacts of E-Commerce to Regional Integration in Southeast Asia
}

\author{
Sukmawani Bela Pertiwi ${ }^{1}$, Amalia Sustikarini ${ }^{2}$, Paramitaningrum ${ }^{3}$ \\ ${ }^{1}$ Faculty of Humanities, Bina Nusantara University, Indonesia, sukmawani.pertiwi@ binus.ac.id \\ ${ }^{2}$ Faculty of Humanities, Bina Nusantara University, Indonesia, amalia.s.suwarno@gmail.com \\ ${ }^{3}$ Faculty of Humanities, Bina Nusantara University, Indonesia, paramitaningrum@ binus.edu
}

\begin{abstract}
This paper aims to examine the social impacts of e-commerce on regional integration in Southeast Asia. This paper argues that the existing literature takes for granted the positive relations between trade and regional integration; define narrowly regional integration in economic terms; and thus, focus mainly on economic impacts of e-commerce to regional integration in Southeast Asia. In contrast to this existing view, regional integration envisioned by ASEAN is not only economic but also social, emphasizing the development of a sense of belonging among regional members. In addition, the logics of the business sector, including e-commerce, may or may not be in line with the logics of ASEAN in imagining regional integration, and thus giving a possibility for the convergence or divergence of interests between the two. Applying constructivist approach on how imagination and transaction contribute to promoting region-ness among regional members, this paper finds that the imagination and transaction of e-commerce actors in the region has not had significant social impact to regional integration and may even develop risk of widening the gap among Southeast Asian countries as the imagination and transaction of many of the e-commerce actors in Southeast Asia are concentrated in the more developed parts of the region.
\end{abstract}

Keywords: E-Commerce, Regional Integration, Southeast Asia, Constructivism

\begin{abstract}
ABSTRAK
Artikel ini bertujuan untuk menganalisa dampak sosial dari perdagangan elektronik terhadap integrasi kawasan di Asia Tenggara. Artikel ini berpendapat bahwa literatur yang tersedia mendefinisikan secara sempit integrasi kawasan dalam kerangka ekonomi sehingga hanya berfokus pada dampak ekonomi dari perdagangan elektronik terhadap integrasi kawasan. Dari sudut pandang yang berbeda, integrasi kawasan yang menjadi visi ASEAN bukan hanya terletak pada aspek ekonomi, tetapi juga pada aspek sosial dengan penekanan pada rasa memiliki di antara anggota kawasan ini. Logika sektor bisnis, termasuk pelaku perdagangan elektronik,dapat atau tidak dapat sejalan dengan logika ASEAN dalam mengimajinasikan integrasi kawasan, sehingga dapat menghasilkan penyatuan atau justru pemisahan kepentingan dari dua entitas ini. Dengan menggunakan pendekatan konstruktivisme dalam melihat kontribusi imajinasi dan transaksi untuk mempromosikan rasa memiliki antar anggota kawasan, artikel ini menyimpulkan bahwa imajinasi dan transaksi dari para pelaku perdagangan elektronik di Asia Tenggara belum menghasilkan dampak sosial terhadap integrasi kawasan. Perkembangan perdagangan elektronik justru berpotensi menimbulkan resiko terhadap melebarnya jarak di antara negara-negara di Asia Tenggara karena imajinasi dan transaksi dari kebanyakan pelaku perdagangan elektronik di Asia Tenggara lebih terkonsentrasi di negara-negara yang lebih maju secara ekonomi di kawasan ini.
\end{abstract}

Kata Kunci : Perdagangan Elektronik, Integrasi Kawasan, Asia Tenggara, Konstruktivisme

\section{Introduction}

In his famous book "Imagined Communities: Reflection on the Origin and the Spread of Nationalism", Benedict Anderson defined a nation as a social construct, which means it is not naturally given but it exists because it is constructed by members of the nation itself. It is an "imagined community" because "the members of even the smallest nation will never know most of their fellow-members, meet them, or even hear of them, yet in the minds of each 
lives the image of their communion". ${ }^{1}$ But a nation, in Anderson's words, is also limited because "even the largest of them encompassing perhaps a billion living human being, has finite, if elastic, boundaries, beyond which lie other nations". ${ }^{2}$ This description of a nation is what then constructivist theorist of International Relations, referred to when they defined a region. ${ }^{3}$

For constructivist, a region is not a simple summation of countries living in geographical proximity nor is it simply a group of countries sharing a similar culture and historical background - even though both are important foundations for a region. The region is socially constructed by actors. ${ }^{4}$ But while in many cases they are constructed first of all by external actors as in the case with region of colonial states and also Southeast Asia which first of all emerged as a British military naming of command in the south of China and the east of India, region is more importantly a product of social construct or imagination of indigenous actors. It is the we-feeling among its members, as Karl W. Deutsch named it, that gives meaning to a region. ${ }^{5}$ In this case, countries may be geographically far apart, but the shared imagination about how interaction in the region should be conducted is what makes a community

\footnotetext{
${ }^{1}$ Benedict Anderson, Imagined Communities: Reflection on the Origin and the Spread of Nationalism (Revised Edition), (London: Verso, 2006), 9.

${ }^{2}$ Anderson, Imagined Communities, 50.

${ }^{3}$ See, Amitav Acharya, The Quest for Identity: International Relations of Southeast Asia, (Singapore: Oxford University Press, 2000). Amitav Acharya, The Making of Southeast Asia: International Relations of A Region. (Ithaca: Cornell University Press, 2012).

${ }^{4}$ See, Acharya, The Making of Southeast Asia.

${ }^{5}$ K.W. Deutsch, Political Community and the North Atlantic Area. In B. F. Nelsen, \& A. Stubb, The European Union: Readings on the Theory and Practice of European Integration, (London: Lynne Rienner Publisher, 2003), 121-143.
}

of countries could be categorized as a region or some would say an integrated region. A popularly known security community in this sense, for example, is a group of countries having shared imagination that their interaction should be conducted by peaceful means. It is a region where war is unthinkable. ${ }^{6}$ And, it is this vision that regional organizations such as the European Union, North Atlantic Treaty Organization, and the Association of Southeast Asian Nations (ASEAN) were originally founded. Given this definition, constructing or integrating a region requires socialization of this imagination to others. For Deutsch, increasing transaction within the region through economic exchanges and mobility of people are central in promoting trust, transparency, shared value, and vision among regional members. ${ }^{7}$ Therefore, many regions, including Southeast Asia, begin their integration with fostering economic integration such apparent in the case of the ASEAN Economic Community (AEC). However, what is less discussed in the existing literature is the fact that it is not only states or group of states that construct the region. Other actors from the business sector, civil societies, prominent individuals, to vernacular groups have their own imagination of the region which may or may not be similar to that of the states. If these imaginations converged, the region becomes more cohesive and integrated. If they differed, the region is not well integrated or even divided.

It is, at this point, that the relations between trade and regional integration become

\footnotetext{
${ }^{6}$ See E. Adler, \& M. Barnett, Security Communities. (Cambridge: Cambridge University Press, 1998).

${ }^{7}$ J. Eayrs, (1958, Feb). "Review: Political Community and the North Atlantic Area: International Organization in the Light of Historical Experience by Karl W. Deutsch," The Canadian Journal of Economics and Political Science / Revue canadienned'Economique et de Science politique, 24 (February 1958): 121-123, doi:http://www.jstor.org/stable/139125
} 
interesting. Trade has long been argued to be the key factor in regional peace and integration. ${ }^{8}$ Therefore, the existing literature focuses more on the economic impacts of trade on regional integration with the increasing trade activities among regional members seen as indicators for a more economically integrated region. The scorecard toward the AEC, for example, measures the progress of the AEC by looking at the increase of the free flow of goods, services, investment, capital, and skilled labor in the region. ${ }^{9}$ The launching of the AEC in the past 2015 was unsurprisingly conducted when all tariff and non-tariff barriers of trade in all the above-mentioned sectors (except agreed) have been eliminated. Given this mainstream belief, the current rising trend of e-commerce in the region is then merely seen as an accelerating factor in regional integration. Compared to the neighboring region in East Asia, e-commerce in Southeast Asia is indeed lagging behind. Retail e-commerce in most Southeast Asian countries, for example, accounted for only $4 \%$ of the total revenue. ${ }^{10}$ However, with a large number of

${ }^{8}$ D.C. Copeland, "Economic Interdependence and War: A Theory of Trade Expectation", International Security, (1996): 8. J. Oneal, F.H. Oneal, Z. Maoz, \& B. Russett, "The Liberal Peace: Interdependence, demcoracy, and International Conflict, 1950-1985", Journal of Peace Research, (1996): 11. Z. Maoz, "The Effects of Strategic and Economic Interdependence on International Conflict Across Levels of Analysis", American Journal of Political Science, (2009): 223-224. E. Gartzke, Globalization, Economic Development, and Territorial Conflict, in M. Kahler, \& F. B. Walter, Territoriality and Conflict in An Era of Globalization, (Cambridge: Cambridge University, 2006), 163. H. Lee \& S. M. Mitchell, "Foreign Direct Investment and Territorial Disputes". Journal of Conflict Resolution, (2012): 675-703. S. Pertiwi, The Rise of Territorial Disputes and the Stability of Southeast Asia. (Washington DC:

American University, 2014).

${ }^{9}$ ASEAN, ASEAN Economic Community Blueprint, (Jakarta: ASEAN Secretariat, 2008).

${ }^{10}$ Competition Commission Singapore, Handbook on E-Commerce and Competition in ASEAN, (Singapore: Competition Commision Singapore). population in the region, the sheer number of young population, the rapid increase of middle class, and the fast internet and mobile penetration, many shared optimism on the growth of e-commerce in the region. ${ }^{11}$ The past two years have revealed this trend as the estimated size of e-commerce in the region has increased more than $50 \%$ from only six billion USD to estimated ten billion in $2017 .{ }^{12}$ The increased presence of global e-commerce players in the region together with the booming of local e-commerce contenders strengthened the lively competition among actors which at the end are expected to foster further regional economic integration as many argued.

However, as mentioned earlier, regional economic integration is only the beginning and one aspect of regional integration. ASEAN itself in its official document mentions that the ultimate purpose of the regional project is to create a community of the ten countries consisting of Indonesia, Malaysia, Singapore, Thailand, the Philippines, Cambodia, Laos, Myanmar, and Vietnam to be "politically cohesive, economically integrated, and socially responsible in order to effectively respond to current and future challenges and opportunities". ${ }^{13}$ In line with the above explanation, the first and the third aspects of this ASEAN integration entail the importance of shared imagination and sense of belonging both at the political and social level before it could be

\footnotetext{
${ }^{11}$ Econsultancy, State of Ecommerce in Southeast Asia. (Singapore: Econsultancy.com, 2014).

ASEANup. (2017, November 8). "Overview of ecommerce in Southeast Asia", ASEANup, retrieved from ASEANup: https://aseanup.com/overview-of-ecommerce-in-southeast-asia/

12 J. Camhi, J. (2017, May 16), "Southeast Asia's Set for Explosive E-Commerce Growth," retrieved from Business Insider: http://www.businessinsider.com/southeast-asias-setfor-explosive-e-commerce-growth-2017-5/?IR=T

${ }^{13}$ ASEAN, The ASEAN Charter, (Jakarta: ASEAN Secretariat, 2008).
} 
politically cohesive and socially responsible and caring each other. This, together with the earlier discussion that business sectors and states may or may not have similar logics or shared imagination of what regional integration should be like, then it could not be taken for granted the view that the growth rate of e-commerce in the region would automatically support regional integration imagined by ASEAN. It is even in our interest to ask: what are the social impacts of e-commerce on regional integration in Southeast Asia?

\section{Theory/Method}

As introduced above, Constructivism as the theory in International Relations emphasized the importance of 1) shared imagination and 2) transactions in promoting regional integration. Questioning the social impacts of e-commerce to regional integration, therefore, implies questioning first of all how e-commerce actors imagine Southeast Asia as a region and whether this imagination is similar to that of imagined by ASEAN. For Julien Cayla \& Giana M. Eckhardt, this could be seen from the selection of brands for the products of these e-commerce actors. ${ }^{14}$ Brands, for the authors, serve the function of the printed newspaper in Anderson's imagined community. It allows people to have a new sense of community with consumers of the same brands beyond their national boundary and identification. In Cayla and Eckhardt terms, "brands mediate new kinds of social relations, enabling the connection between people who may have never seen each other". ${ }^{15}$ In this sense, what the e-commerce actors select and omit in creating their brand is part of the process of "remapping and redefining" the region in line with their imagination. ${ }^{16}$ According to Cayla and

${ }^{14}$ J. Cayla \& G. M. Eckhardt, "Asian Brands and the Shapping of A Transnational Imagined Community", Journal of Consumer Research, 35, (August 2008):

216

${ }^{15}$ Cayla \& Eckhardt, "Asia Brands”, 218

${ }^{16}$ Cayla \& Eckhardt, "Asia Brands”, 226
Eckhardt, there are two indicators that could be used to analyze the actor's imagination of a region judging from their brand. First, how actors "deterritorialize" and "unmoor" the brand from a particular country, meaning how actors create a brand that shifts their imagination away from their home country. ${ }^{17}$ This can be regional or global. Therefore, related to this paper, this first indicator could be used to examine in what levels e-commerce actors in the region imagine the scope of their potential consumer community. If the selected scope is regional and it is in line with the scope of region imagined by ASEAN as to include the ten countries in Southeast Asia, then e-commerce has positive impacts to integration in the region. Second, how actors describe the imagined community. Brands that imagine their consumer community to be dynamic urban-based, for example, would tend to influence the young urban population, which then raise more sense of belonging among this section of the population compared to others. This selected description by e-commerce actors in the region would then help explain which sections of the community that have stronger we-feeling or which section are more integrated into Southeast Asia. However, several actors also use the strategy of "multicultural collage" whereby in order to create a brand that could go beyond national boundaries, actors tend to demonstrate that they embrace different components of society in their imagined community. ${ }^{18}$ Yet again, this would have implications that any components included in this imagery would tend to have a stronger sense of belonging compared to others. Nevertheless, it is also worth to note Cayla and Eckhardt finding ${ }^{19}$ of the answer given by the managers when asked about their imaginations of Asia. The managers focus on the urban centers of Asia such as Shanghai, Hongkong and Singapore as

\footnotetext{
17 Ibid.

${ }^{18}$ Cayla \& Eckhardt, "Asia Brands," 226

${ }^{19}$ Cayla \& Eckhardt, “Asia Brands,” 218
} 
their imaginary center of Asia. The emphasis on "class" that is represented by urban and elite groups might only partially cover the society of Asia. This tendency must also be considered when we analyze the imagination of Southeast Asia. Rather than promoting regional integration, this exclusivity will potentially be impeding the society cohesiveness.

In the second level, questioning the social impacts of e-commerce to regional integration also implies questioning how ecommerce actors promote transactions that could increase integration across the region. According to Karl W. Deutsch, regional integration should not only occur at the elite political level but must also occur at the societal level, because again, it is the we-feeling among members in the region that would give meaning to the region itself. ${ }^{20} \mathrm{In}$ his argument, while shared imagination among regional members is important, the transaction is no less important because it is the transaction that would enable socialization of this shared regional imagination to as many members across the region and it is a transaction that would help to build mutual trust and understanding among people within the region. E-commerce, in this case, similar with other economic exchanges, is supportive of regional integration not only by increasing the cost of cutting off trading relations as many have observed but also by increasing emotional attachment among people within the e-commerce ecosystem itself. The effectiveness of the role of e-commerce, however, depends on at least three main circumstances: that the transaction must include multiple areas, must be durable enough to ensure mutual dependency, and must be based on common values. ${ }^{21}$ If these two aspects of the theoretical framework of constructivism summarized in a model of an analytical tool to

${ }^{20}$ Deutsch, "Political Community," 121-143

${ }^{21}$ Eayrs, "Review: Political Community," 121-123, answer the research question of this paper, it would be as Figure 1.

Finally, based on this theoretical framework, this paper proposes an argument that e-commerce has social impacts to regional integration in Southeast Asia through their unique imagination and transaction which may or may not be in line with regional integration imagined by ASEAN. How they deterritorialize and describe their consumer imagined community together with the scope, durability, and values of their transactions in the region would lead to their positive or negative impacts on the regional integration.

To elaborate this argument, this paper uses a qualitative method based on the consideration that the main focus of this research is examining the imagination of e-commerce actors in its relations to regional integration which is characteristically non quantifiable. Even though the impacts of actors' transaction could be measured statistically, the durability and values of the transaction are also nonquantifiable, and thus more suitable for qualitative analysis. In applying this method, this research is divided into three steps. First of all, this paper identifies major e-commerce actors in the region. Since no dataset available across the ten countries in the region, this paper creates a new dataset from various sources, particularly from iprice group and ecommerceiq, which list the top five e-commerce actors in each member country based on their website traffic in 2017. ${ }^{22}$ The assumption is that website

22 "The Map of E-Commerce in Indonesia," iprice, last modified June 2017, retrieved from iprice insights:

https://iprice.co.id/insights/mapofecommerce/en/. ecommerceiq. (2017). "Indonesia," ecommerceiq, last modified 2017, retrieved from Ecommerce IQ: https://ecommerceiq.asia/top-ecommerce-sitesindonesia/. "iprice insights," last modified June 2017, retrieved from The Map of E-Commerce in Malaysia: https:/iprice.my/insights/mapofecommerce/en/. 
traffic would reflect the scope and the number of transaction of the individual e-commerce actor as well their influence in that country or even at the regional level. Given the small numbers of actors that have expanded their activities beyond national boundaries, the research limits the list in each country only to five e-commerce actors. Limiting the number of actors also beneficial in narrowing the gap between a country with the most developed and country with the least developed e-commerce sector such as Laos which has very few players and even none are registered at the government system. Other criteria applied to this dataset is the limit on the type of players as to include only B2C (Business to Consumer) and $\mathrm{C} 2 \mathrm{C}$ (Consumer to Consumer) actors while excluding the B2B (Business to Business) actors because of the focus of this paper on examining the role of ecommerce in promoting regional integration at the societal level. It is also for this reason that the list contains only a marketplace type of ecommerce where social interaction is massive compared to other types of e-commerce. However, the paper excludes e-commerce conducted at social media because of the difficulty of measurement in relations to its

"Malaysia," last modified 2017, retrieved from Ecommerce IQ: https://ecommerceiq.asia/topecommerce-sites-malaysia/. "The Map of ECommerce in Thailand," last modified June 2017, retrieved from iprice insights:

https://ipricethailand.com/insights/mapofecommerce/ en/. iprice. (2017, June). "The Map of E-Commerce in the Philippines," last modified June 2017, retrieved from iprice insights:

https://iprice.ph/insights/mapofecommerce/. "Philippines," last modified 2017, retrieved from ECommerce IQ: https://ecommerceiq.asia/topecommerce-sites-philippines/. iprice. (2017, June).

"The Map of E-Commerce in Vietnam," last modified June 2017, retrieved from iprice insights: https://iprice.vn/insights/mapofecommerce/en/. "Vietnam," last modified 2017, retrieved from ECommerce IQ: https://ecommerceiq.asia/topecommerce-sites-vietnam/ multipurpose function both for economic and non-economic activities. Finally, based on these criteria, the dataset could be summarized as Table 1 . The following step is analyzing actors' imagination of Southeast Asia by examining the brand they use to market their products using Cayla and Eckhardt's indicator explained earlier. This includes how actors deterritorialize and describe their imagined community. The last step is analyzing actors' transaction. In terms of the durability of the transaction, this paper uses the distribution of branches or representative offices as its parameter. According to regime theory, institutionalized cooperation demonstrates long term commitment, and thus the presence of branches or representative offices demonstrates long term commitment of transaction in the region. However, this does not necessarily mean that the absence of the institution implies no transaction. Many ecommerce actors offer shipping services across regional countries, which even though could be a testing-the-water step before deciding to open branches or representative offices in the future, could at the moment demonstrate their shortterm commitment of transaction in the region. In terms of the area of transaction, this paper uses the scope of exchanges as its parameter. This includes goods, services; investment, capital, and skilled labor with the more areas of exchanges demonstrate greater transaction that could be potentially translated into greater integration particularly if these areas are in line with those prioritized by the ASEAN integration. Last, in terms of value, this paper uses company value or identity as its parameter. The transaction has a greater social impact on regional integration if it is based on a common value. Therefore, the compatibility between company value or identity with those promoted by ASEAN and the consumers demonstrate stronger impacts on regional integration. 
171 Sukmawani Bela Pertiwi, Amalia Sustikarini, dan Paramitaningrum | The Impacts of E-Commerce to Regional Integration in Southeast Asia

Figure 1. Model Explaining Social Impacts of E-Commerce to Regional Integration

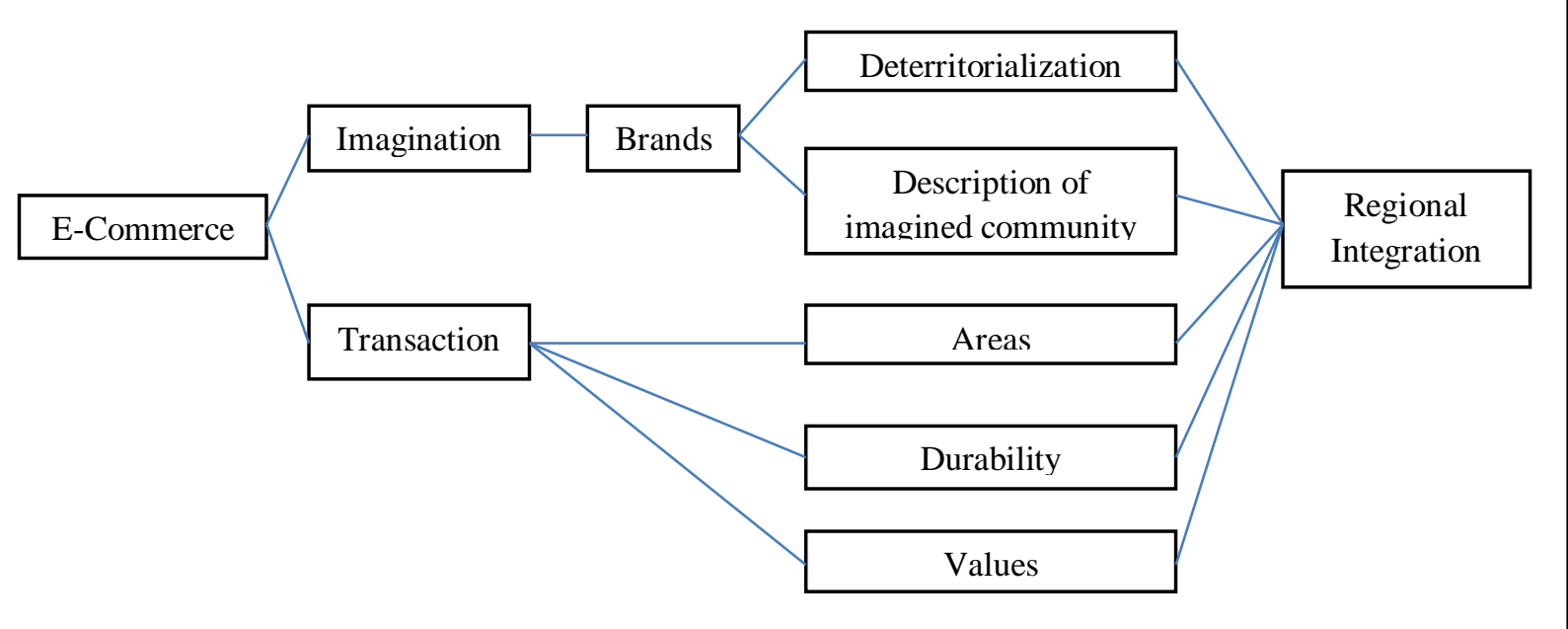

Table 1. List of Major E-Commerce Players in Southeast Asia

\begin{tabular}{|c|c|c|c|c|}
\hline Indonesia & Malaysia & Singapore & Thailand & The Philippines \\
\hline - $\quad$ Lazada & - $\quad$ Lazada & - $\quad$ Qoo10 & - $\quad$ Lazada & - $\quad$ Lazada \\
\hline - Tokopedia & - 11 street & - Lazada & - 11 street & - Zalora \\
\hline - Elevenia & - Lelong & - Carousell & - Shopee & - Shopee \\
\hline - Bukalapak & - Shopee & - Zalora & - Chilindo & - Ebay \\
\hline - $\quad$ Blibli & - Zalora & - $\quad$ Ezbuy & - NotebookSPEC & - Beauty MNL \\
\hline Brunei Darussalam & Vietnam & Cambodia & Laos & Myanmar \\
\hline - QQestore & - $\quad$ Lazada & - Glad Market & - $\quad$ Yula.la & - $\quad$ Shop.com.mm \\
\hline - DHGate & - The Gioi Dong & - Shope165 & - Bydala & - $\quad$ Shwe99 \\
\hline - Zalora & - $\quad$ Sendo & - Mall855 & - Bestbuy & - Onekyat \\
\hline - Fashion Valet & - $\quad$ Tiki & - Maiomall & & - Zawgyinmart \\
\hline - $\quad$ Aliexpress & - Vat Gia & - $\quad$ Khmer24 & $\bullet$ & - MyanmarcarsDB \\
\hline
\end{tabular}

\section{The State of E-Commerce in Southeast Asia}

The phenomenon of E-Commerce in Southeast Asia is relatively new compared to other more developed regions. Even in the traditional economy, Southeast Asian economy is often overshadowed by its rapidly developed neighboring region of East Asia which is now also becoming the new center of gravity for the global economy. As well-described in a flying geese model, Southeast Asian countries only began their economic reform after and partly as a spillover effect of the economic development in East Asia. Therefore, the stage of economic development in the region is lagging behind its neighbour and this also explains why investors overlook at Southeast Asian economy compared to that of East Asia. Parallel to this, the growth of e-commerce in the region as a form of a more developed economic activity which requires advanced technology infrastructure is also lagging behind. 
However, there are several reasons why e-commerce eventually found its breeding ground in Southeast Asia and make the region the fastest-growing region for e-commerce. First of all, market saturation in East Asia pushes investors to expand their market outside the region in order to leap more profit. The absence of significant players in the region makes Southeast Asia an "untapped market" for these investors. ${ }^{23}$ Moreover, secondly at the regional level, ASEAN is pushing regional economic integration which results in a huge market creation of an estimated 630 million people or greater than the EU. The economic integration under the umbrella of the AEC also eases market regulations and other trade barriers among member countries which in the past often hinder investors to invest their money in the region. This becomes even more attractive with the fact at the grassroot level that the number of the middle-class population grows significantly in all Southeast Asian countries and the percentage of young population overwhelmingly dominate the population pyramid accounting for two-third of the total population. ${ }^{24}$ The combination of these two factors implies that the market potential for e-commerce, that is the number of the population having purchasing power and knowledge in conducting e-commerce activity, is more than significant and will continue to grow in the future. Finally, all this development is enhanced with the rapid internet and mobile penetration as the minimum technology infrastructure for e-commerce in which roughly $34 \%$ of the total population in the region is now connected to the internet. ${ }^{25}$

With all these mutually reinforcing factors, various e-commerce actors began to

\footnotetext{
23 "Overview of e-commerce in Southeast Asia", ASEANup

24 Ibid.

${ }^{25}$ Competition Commission Singapore, Handbook on

E-Commerce and Competition in ASEAN.
}

flood the region, small portion in the form of global actors expanding their reach to the region while the bigger portion in the form of local startup companies. There are several unique characteristics of these e-commerce actors in the region. First, the global actors participating in regional competition are very limited. Amazon as the US-based e-commerce giant that has traditionally dominated global wholesale marketspace has not yet set their feet in the region, leaving the region dominated by the Chinese leading wholesale platform, the Alibaba Group. Other global actors such as eBay or 11Street, even though presents in several Southeast Asian states only play minor roles in each Southeast Asian country. This picture, on the one hand, reflects the reluctance of the global actors in the nascent market of the region. On the other hand, this reflects the political economy of the region where it witnesses the decline of the US power and the rise of China's hegemonic power. Secondly, the minor role of these global actors, coupled with the regional context that is heterogeneous in a topographical landscape, rich in culture, and diverse in the level of economic development makes a one-forall regional strategy difficult. ${ }^{26}$ This also explains why no global players dominate and play a significant role in each country in the region. As mentioned earlier, even though Alibaba is the biggest actor in the region, it could not dominate or even lead the domestic market of each Southeast Asian country. This, at the same time, also explains the rise of small local startups companies which interestingly dominate the market of each member country. Some examples are Tokopedia in Indonesia, Lelong in Malaysia, or Carousell in Singapore. Only several companies could expand beyond national boundaries, such as Lazada, Qoo10, Zalora, and Shopee. Lazada deserves special mention as perhaps it is the only actor that has a

\footnotetext{
${ }^{26}$ Econsultancy, State of Ecommerce in Southeast Asia.
} 
regional vision and, in practice, has become the biggest and only local e-commerce actor in the region. Interestingly, the third uniqueness of the e-commerce phenomenon in the region is that most of these local actors are backed by a small number of foreign venture capitals such as Rocket Internet, Alibaba, and Ardent Capital. Alibaba is not only the biggest global actor in the region with its own brand Aliexpress, but it is also the main investor in Lazada and several other local startups, making the seemingly competitive market becomes oligopolistic in nature. Last but not least, e-commerce in Southeast Asia is also unique in terms of the distribution of these actors. While it is not surprising to see more international actors in the ASEAN 6 countries, the distribution of local ecommerce actors is more even in almost all Southeast Asian countries. However, two are outstanding. Laos is the least developed country in e-commerce judging from the few numbers of e-commerce players in the country, while Myanmar which many would consider as the latest comer in e-commerce have more players in its market.

\section{The Imagination of E-Commerce Actors and Regional Integration}

The increasing number of e-commerce actors flooding Southeast Asian market together with their unique characteristics makes it important to question their impact to regional integration which, as mentioned earlier, could be seen from their imagination of the region: whether they have a regional vision and whether this vision is in line with that of promoted by ASEAN. Based on the list of key e-commerce actors included in this research, there are two main findings. First, in terms of deterritorialization or how actors promote their imagined community by shifting consumers' imagination from their home territory, it appears that there are variations of levels at which e-commerce actors want to build their imagined community. It means not all of them to have a regional vision or imagination of Southeast Asia as their marketplace. International actors, such as Ebay, Aliexpress, and 11Street unquestionably locate their imagined marketplace at the international level. Ebay, for example, clearly mentions its brand to be "the world's favorite destination for discovering great value and unique selection". ${ }^{27}$ Aliexpress and 11Street indicate their globalness by mentioning no reference of level in their brand. Aliexpress markets itself under the tagline "smarter shopping, better living", while 11 Street markets itself as "the best way to $\mathrm{K}$ Shopping". ${ }^{28}$ Both, however, mention their customer and delivery to include those across countries.

In the other extreme, the majority of local actors have defined their market niche within each domestic market. Bukalapak and Blibli in Indonesia brand themselves as "the trusted site for online shopping in Indonesia" and "the pioneer of the biggest and the most complete online mall in Indonesia" respectively. ${ }^{29}$ In Malaysia, the biggest local actor, Lelong, develops its brand as "the largest online shopping marketplace in Malaysia". ${ }^{30} \mathrm{In}$ Thailand, NoteSPEC describes itself as "the \#1 notebook community in Thailand". ${ }^{31}$ Beauty

\footnotetext{
27 “Our Company," ebay, retrieved from ebay: https://www.ebayinc.com/our-company/

28 "Aliexpress," Aliexpress, retrieved from Aliexpress: https://www.aliexpress.com. "About 11Street," 11Street, retrieved from 11Street: http:/global.11st.co.kr/en/browsing/EventPromotion. tmall?method=getEventPromotion \&dispObjNo=9885 614

29 “Tentang Bukalapak," Bukalapak, retrieved from Bukalapak: https://www.bukalapak.com/about. "Tentang Blibli.com," Blibli, retrieved from Blibli.com: https://www.blibli.com/panduanbelanja\#hash-side-tentangBlibli

30 "Lelong," Lelong, retrieved from Lelong: https://www.lelong.com.my 31 "NoteSPEC," NoteSPEC, retrieved from NoteSPEC: https://notebookspec.com
} 
MNL in the Philippines appeals its potential consumer community with its brand "finally one for the Filipina", meanwhile Vat Gia in Vietnam uses the brand "the leading e-commerce portal in Vietnam". ${ }^{32}$ In Cambodia, all the listed actors identify their national imagination with brands such as "Cambodia's local online marketplace", "one of the leading and largest online products in Cambodia", "the no.1 online shopping marketplace in Cambodia, and "buy and sell everything in Cambodia". ${ }^{33}$ Yula.la and Bydala in Laos both use national brands with the tagline "free online classifieds to buy and sell your stuff in Laos" and "online shopping in Laos". ${ }^{34}$ Last, in Myanmar, the listed companies use brands such as "online Myanmar shopping store", "Myanmar buy and sell", "e-commerce business in Myanmar", and "used cars, new cars, buy and sell in Myanmar". ${ }^{35}$ Most of these actors not only limit their brands within their imagined national boundaries but also use national language as their main language for communication. Only small numbers of the listed e-commerce actors have explicit global visions, such as Tokopedia in Indonesia, Ezbuy in Singapore, DHgate in Brunei Darussalam, and

\footnotetext{
${ }^{32}$ MNL, B. (n.d.). About Us. Retrieved from BeautyMNL: https://beautymnl.com/company. "Vat Gia," Vat Gia, retrieved from Vat Gia: https://www.vatgia.com/home/

33 "About Glad Market," Glad Market, retrieved from Glad Market:

http://www.gladmarket.com/about.html. "Mall855," Mall855, retrieved from Mall855: http://www.mall855.com. "MAIO Mall," MAIO Mall, retrieved from MAIO Mall: http://www.maiomall.com. "Khmer24," Khmer24, retrieved from Khmer24: https://www.khmer24.com 34 "Yula.la," Yula.la Retrieved from Yula.la: http://yula.la. "Bydala," Bydala, retrieved from Bydala: http://bydala.com

35 "Shwe99," Shwe99, retrieved from Shwe99: http://www.shwe99.com. “One Kyat,” One Kyat, retrieved from One Kyat: https://www.onekyat.com. "About Us," Zwagyin Mart, retrieved from Zwagyin Mart: http://www.zawgyimart.com/about. "CarsDB," CardDB, retrieved from CarsDB:

https://www.carsdb.com/en
}

Sendo in Vietnam. ${ }^{36}$ Similarly, only small numbers of them have regional visions with shop.com.mm and Qoo10 places their imagined community. ${ }^{37}$ Thus, from the list of the local ecommerce actors, none have an imagination of Southeast Asia as their marketplace.

It is these gaps that three listed regional e-commerce actors such as Lazada, Zalora, and Shopee try to fill - the untapped market of Southeast Asia. From the beginning, the three actors are designed to focus on Southeast Asian market with Lazada identifies itself as "Southeast Asia's No.1 Online Shopping and Selling Destination", Zalora as "Southeast Asia's largest online fashion platform", and Shopee as "the first mobile platform in Southeast Asia". ${ }^{38}$ Similar with the discussion in earlier section, the three of them decide to focus on Southeast Asia because of the future potential of the region in terms of the increasing middle class and information technology infrastructure. On the one hand, this is encouraging and positive for regional integration because it would help to strengthen shared imagination as part of Southeast Asia among people and seller community within each network. In fact, each company has its own seller center and nurture their seller community online through social media and offline through conferences or

\footnotetext{
36 “About," Tokopedia, retrieved from Tokopedia: https://www.tokopedia.com/about. "Ezbuy," Ezbuy, retrieved from Ezbuy: https://ezbuy.sg. "DHGate," DHgate, retrieved from DHGate:

https://www.dhgate.com. "Sendo," Sendo, retrieved from Sendo: https://www.sendo.vn

37 “About Us," Daraz, Retrieved from Daraz: https://www.daraz.pk/about/. "About Qoo10 \& Giosis," Qoo10, retrieved from Qoo10: https://www.qoo10.com/gmkt.inc/Company/AboutCo mpany.aspx

38 "Lazada," Lazada, retrieved from Lazada: http://lazada.co.id. "About Zalora," Zalora, retrieved from Zalora: https://www.zalora.com.my/about/. "Shopee," Shopee, retrieved from Shopee: http://shopee.co.id
} 
gatherings. On the other hand, this might not have significant impacts because, as explained earlier, it is difficult to apply a one-for-all strategy in all Southeast Asian countries given the heterogeneity of the Southeast Asian landscape. As a result, regional actors such as Lazada will have a subsidiary in each country that is independent enough from the regional parent and local enough to meet the domestic market. The consequence is that these regional actors are, then, not different from local actors with transactions and community engagement also limited to the national boundary. Lazada, for examples, has more seller gatherings at the national level rather than at the regional level. In this circumstance, actors' imagination on Southeast Asia as a region is undermined by their country-specific strategy which in the end reduces their impact to regional integration as well.

But, it is still worth understanding which section of community that these regional companies are trying to build or, as stated in the second aspect, how actors describe their imagined community, because only by answering this question that it will be clearer which segment of Southeast Asian community that has potentially greater sense of belonging due to greater exposure and interactions with their counterparts across the region. From the three regional companies that locate their imagined community in Southeast Asia, the three actors, similar with the majority of other online marketplaces, target wider audience who are actively using mobile phone or desktop for their daily activities. ${ }^{39}$ Shopee, in particular, deliberately focus on their mobile market, given

\footnotetext{
${ }^{39}$ Maulana, Y., CEO Shopee: Kami Ingin Masyarakat Semakin Memahami e-commerce, 13 February 2017, retrieved from Swa: https://swa.co.id/swa/ceo-interview/ceo-shopeekami-ingin-masyarakat-semakin-memahami-ecommerce
}

mobile phone users in the region outnumbered the desktop users. In fact, Shopee's vision is to fill the gap in the absence of big players in the mobile platform in the region. In other words, this trend implies that e-commerce actors tend to target younger and technology-savvy population, with Zalora specifically focus on 20-35 years old audience. ${ }^{40}$ Given its more specific focus on fashion, Zalora also limits its target market to the women and middle-income population who enjoy online shopping. ${ }^{41}$ In terms of the seller community, both Lazada and Shopee target young entrepreneurs and startup companies to join their market. In conclusion, while no survey has been conducted on the ASEAN Awareness across market segmentation, the fact that these actors engage more with younger, technologically literate, and middle-income population implies that these segments of the community have better information and exposure with products and seller from other countries. This segmented market leads to the question about the inclusivity of e-commerce. While the engagement in this segment is beneficial to enhance the company's profit, this could discourage the integration of the region in terms of societal cohesiveness. E-commerce will be seen as 'the upper-middle-class business' in the region. The localization strategy of these regional companies also means that more interaction remains at the national level. From the imagination of e-commerce actors, finally, it can be concluded that it has no significant impact on regional integration in Southeast Asia.

\footnotetext{
${ }^{40}$ Marketeers Editor, Strategi Zalora Kembangkan Bisnis di Indonesia, 27 September 2015, retrieved from Marketeers: http://marketeers.com/strategizalora-kembangkan-bisnis-di-indonesia/ ${ }^{41}$ Ibid.
} 


\section{The Transaction of E-Commerce Actors and Regional Integration}

Southeast Asia is one of the regions with significant growth of the online market. Since 2015 , the number of internet users in the six largest economies in ASEAN has risen from 244 million to 283 million, and this growth is projected to continue at an annual rate of $17.7 \%$ until 2022. ${ }^{42}$ Google and Temasek Holding projected that Southeast Asia e-commerce sales could reach U\$88 billion by $2025 .{ }^{43}$ However, beyond the promising numbers, there are several qualitative aspects of a transaction that warrant closer analysis. This paper uses durability, area and value as the elements of a transaction by using the dataset in Table 2.

\section{a. Durability}

The durability of a transaction is portrayed by the presence of the branch offices of the market place in the region. Given the borderless nature and liquidity of the e-commerce market, the existence of a physical office is somehow not necessarily important. However, the establishment of a representative office will represent commitment; build a sense of belonging, in addition to supporting practical and bureaucratic purposes. From the three levels of the market place, global players such as Ebay open their local office in selected countries. Ebay has a local office in Thailand and plans to open another one in Jakarta, Indonesia (Freischland 2016), while Alibaba just opened its branch in Singapore. 11Street has offices in Thailand and Malaysia. The "regional" marketplace such as Lazada, Zalora and Shopee have more branches than their global

\footnotetext{
${ }^{42}$ Competition Commission Singapore, Handbook on E-Commerce and Competition in ASEAN.

43 "Amazon, Alibaba Tussle in South-east Asia", Straitimes, retrieved from 24 October 2017, https://www.straitstimes.com/business/amazonalibaba-tussle-in-south-east-asia
}

competitors. Lazada puts grips in ASEAN 6 countries: Singapore, Malaysia, Thailand, Philippines, Indonesia and Vietnam. Zalora opens its branches in Malaysia, Singapore, Indonesia, Philippines and Brunei. Shopee, the newest player that identifies itself as the leading e-commerce platform in Greater Southeast Asia, looks aggressive to open branches also in ASEAN 6 countries. The national marketplace seems reluctant to open branches outside their home country. It is reasonable because establishing foreign branch equals to additional operational cost.

From the establishment of a branch, it can be seen that the regional marketplaces are eyeing ASEAN 6 countries due to their lucrative market with a significant number of the middle class and impressive economic growth. The absence of a local office of the regional marketplace in the other three countries: Cambodia, Laos and Myanmar imply the segregation of the e-commerce market in this region. These three countries are potential to be the destination of e-commerce business but are often hampered by the lack of infrastructure. 
177 Sukmawani Bela Pertiwi, Amalia Sustikarini, dan Paramitaningrum | The Impacts of E-Commerce to Regional Integration in Southeast Asia

Table 2. Transaction of E-Commerce in Southeast Asia

\section{Major E Commerce Actors}

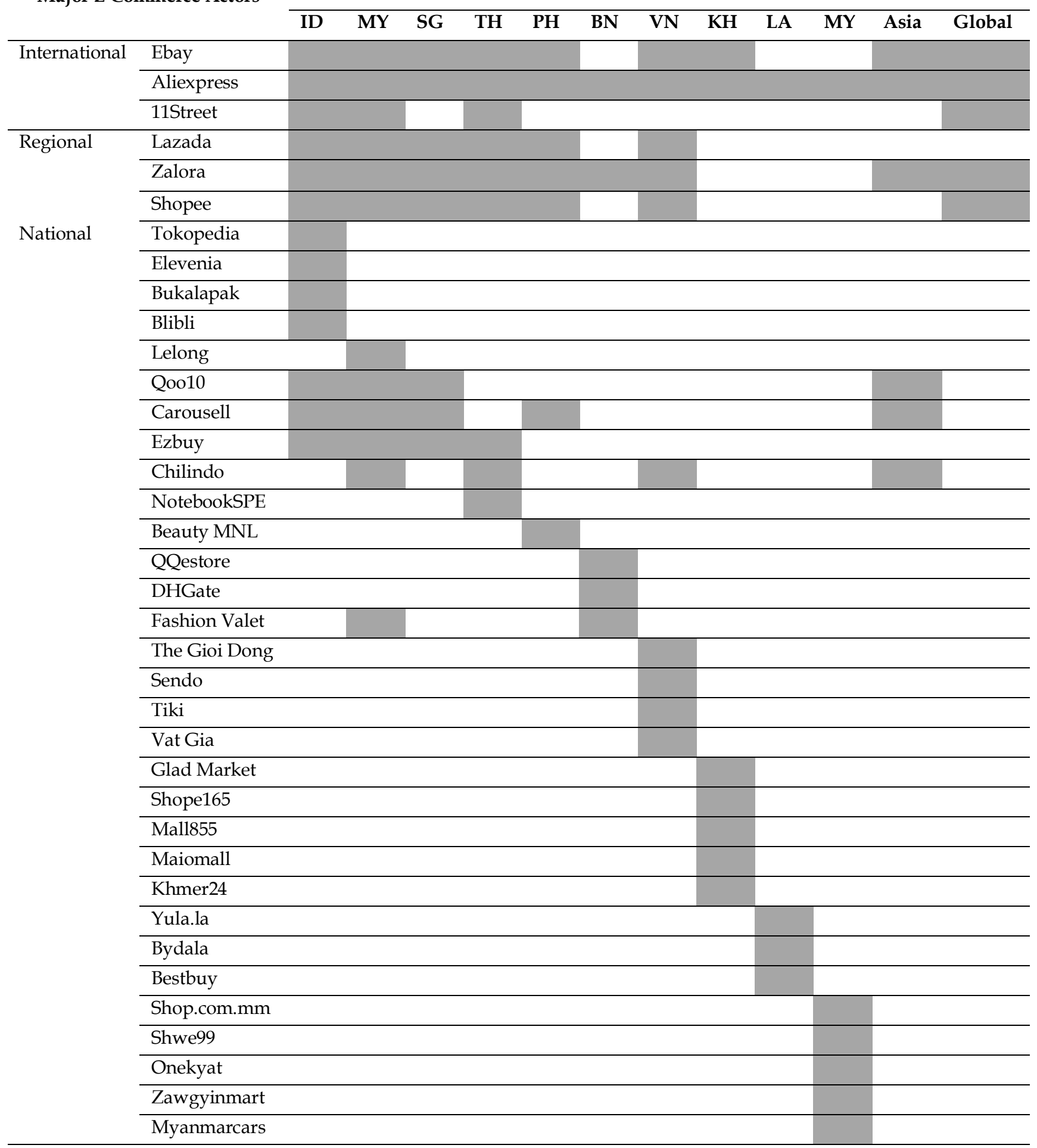

\section{b. Area}

This paper utilizes the scope of the transaction to analyze the aspect of the area. The scope of the transaction can cover a wide range of aspect from goods and service, capital, investment and skilled labor. Goods which are traded among 
marketplaces in this region are dominated by international brand and local brand. There is no reliable figure to depict the variety and numbers of goods produced by Southeast Asian countries that are sold and bought within the region by the regional marketplace. The intra-regional commercial is also hampered by several hurdles: the cost of courier/expedition, inter-country tax/custom, and online payment.
In terms of skilled labor in the ecommerce business, the scope of exchange is dynamic. However, this is not a reflection of the scope of exchange in Southeast Asia because the skilled labor is dominated by IT professionals whose mobility is beyond the regional sphere. Lastly, in investment and capital realm, there are several Southeast Asia based venture capitals, but the global player also joins the market such as Alibaba \$1 billion investment to Lazada.

Figure 3. Five Largest Southeast Asia Based Venture Capital Investors by Assets Under Management

\begin{tabular}{llll}
\hline Investor & Type & Location & Assets \\
\hline GIC & Sovereign Wealth Fund & Singapore & 350 \\
OCBC Bank & Bank & Singapore & 291 \\
United Overseas Bank & Bank & Singapore & 241 \\
Temasek Holdings & Sovereign Wealth Fund & Singapore & 198 \\
Employees' Provident & Public Pension Fund & Malaysia & 170 \\
Fund & & & \\
\hline
\end{tabular}

Source : Preqin Venture Capital Online, 2016 (http://docs.preqin.com/reports/Preqin-Venture-Capital-SoutheastAsia-September-2016.pdf 2016)

Figure 4. Five Largest Southeast Asia-based Venture Capital Fund Managers by Total Capital Raised in the Last 10 Years Firm Location Estimated

\begin{tabular}{|c|c|c|c|}
\hline Firm & Location & Estimated Dry Powder (\$mn) & $\begin{array}{l}\text { Total Capital Raised in Last } 10 \text { years } \\
(\$ \mathrm{mn})\end{array}$ \\
\hline Axiom Asia Private & Singapore & 896 & 2.931 \\
\hline \multicolumn{4}{|l|}{ Capital } \\
\hline L Capital Asia & Singapore & 72 & 1,642 \\
\hline TAEL & Singapore & 336 & 1.251 \\
\hline Gateway & Singapore & 476 & 555 \\
\hline CX Capital & Singapore & - & 515 \\
\hline
\end{tabular}

Source : Preqin Venture Capital Online,2016

\section{c. Value}

Value or identity of a company, in this case, the marketplace, is another important aspect to analyze the transaction aspect of e-commerce in Southeast Asia. The compatibility between company value and ASEAN value will be a positive factor to support regional integration. This article utilizes selected ASEAN Economic Community pillars as ASEAN values. Competitive Economic Region and Equitable Economic Development could be used as values.
Consumer protection is one of the aspects of the competitive economic region while the development of SMEs is the backbone of equitable economic development. Consumer protection is a very important aspect of ecommerce due to its virtual nature. Shopee uses tagline "Shopee Guarantee" to protect users (buyer and seller by withholding the payment to sellers until the buyers confirm receipt of the 
orders. ${ }^{44}$ Lazada and Zalora mention consumer protection as their concern even though they do not make any specific campaign or tagline. In supporting Small and Medium Enterprises as the element of equitable and inclusive trade, Lazada launched \#EveryoneCanSell campaign to help local SMEs to grow their online business by forming a strategic alliance with Lazada. ${ }^{45}$ Shopee is also actively supporting SMEs in their supply chain. They make a video in youtube to show how Shopee empowers SMEs in Indonesia, especially by offering free delivery cost and course on online trade. The aspect of company value can give more benefit to the region if it can steadily be maintained, especially the integration of SMEs, given the fact that SMEs are the major economic player in the region.

In sum, the several aspects of the transaction (durability, area and value) do not seem to positively correlate to regional integration. The establishment of the branch only evident in the top six ASEAN countries, while the inter-region transaction of trade is hampered by multiple problems. The most common feature of transaction aspect in e-commerce that it is mostly available in either international or local domain and not at the regional level. The strong emphasis of the e-commerce on the countryspecific strategy and the preference of the market penetration to the ASEAN six countries, coupled by the focus on the upper-middle class consumer would potentially widen the development gap between ASEAN member

${ }^{44}$ https://help.shopee.com.my, retrieved 10 December 2017, from https://help.shopee.com.my/hc/enus/articles/115007181827-What-is-Shopee-

Guarantee-How-does-it-work-

${ }^{45}$ https://liveatpc.com. (n.d.). Retrieved 12 10, 2017, from https://liveatpc.com/lazada-helps-smes-groweveryonecansell/ countries and income gap within ASEAN's member countries. These gaps are definitely not a driving force for the integration of the region.

\section{Conclusion}

This research demonstrates two important findings. First, trade does not always correlate positively with regional integration. Second, the impact of trade on regional integration is not limited to the economic aspect but it also has a social impact. In the case of e-commerce in Southeast Asia, it appears that the social impact of e-commerce to regional integration could be seen from the imagination of e-commerce actors of its marketplace and its transactions within the region. From the former, this research found that most of the e-commerce actors imagine their marketplace well within their own national boundary. It means that their imagination does not contribute significantly to increasing regional sense of belonging among its community. From the later, this research found that most of the e-commerce actors engage in more intense transactions in the ASEAN 6 countries (Indonesia, Singapore, Malaysia, Thailand, the Philippines, and Vietnam) compared to the rest. This poses the risk of dividing the region as the exposure and interaction is greater in the former rather than the later.

\section{References}

\section{Books}

Acharya, Amitav.The Quest for Identity: International Relations of Southeast Asia. Singapore: Oxford University Press, 2000. 
180 Sukmawani Bela Pertiwi, Amalia Sustikarini, dan Paramitaningrum | The Impacts of E-Commerce to Regional Integration in Southeast Asia

Acharya, Amitav.The Making of Southeast Asia: International Relations of A Region. Ithaca: Cornell University Press, 2012

Adler, Emanuel., \& Barnett, Michael.Security Communities. Cambridge: Cambridge University Press, 1998.

Anderson, Ben. Imagined Communities: Reflection on the Origin and the Spread of Nationalism (Revised Edition). London: Verso, 2006.

ASEAN. ASEAN Economic Community Blueprint. Jakarta: ASEAN Secretariat, 2008

ASEAN. The ASEAN Charter. Jakarta: ASEAN Secretariat, 2008.

Competition Commission Singapore. Handbook on E-Commerce and Competition in ASEAN. Singapore: Competition Commision Singapore, (n d)

Deutsch, Karl. Political Community and the North Atlantic Area. In B. F. Nelsen, \& A. Stubb, The European Union: Readings on the Theory and Practice of European Integration, 121-14. London: Lynne Rienner Publisher, 2003.

Deutsch, Karl. The Political Community and the North Atlantic Area. Princeton: Princeton University Press, 1957.

Gartzke, Erik.” Globalization, Economic Development, and Territorial Conflict. In M. Kahler, \& F. B. Walter, Territoriality and Conflict in An Era of Globalization, 163). Cambridge:

Cambridge University, 2006

\section{Journals:}

Cayla, Julien., \& Eckhardt, Giana. "Asian Brands and the Shapping of A
Transnational Imagined Community", no 35 (2008) : 216-230.

Copeland, Dale. "Economic Interdependence and War: A Theory of Trade Expectation", International Security, no 8 (1996)

Eayrs, James. "Review: Political Community and the North Atlantic Area: International Organization in the Light of Historical Experience by Karl W. Deutsch", The Canadian Journal of Economics and Political Science / Revue canadienned'Economique et de Science politique, no 24 (1958) : 121-123. doi:http://www.jstor.org/stable/139125

Lee, Hon., \& Mitchell, Sara. (2012). Foreign Direct Investment and Territorial Disputes. Journal of Conflict Resolution, (2012) : 675-703.

Maoz, Zeev. The Effects of Strategic and Economic Interdependence on International Conflict Across Levels of Analysis. American Journal of Political Science, (2009) : 223-224.

Oneal, John., Oneal, Frances.,Maoz, Zeev., \& Russett, Bruce. The Liberal Peace: Interdependence, demcoracy, and International Conflict, 1950-1985. Journal of Peace Research, no 11 (1996).

\section{Thesis:}

Pertiwi, Sukmawani. The Rise of Territorial Disputes and the Stability of Southeast Asia. Washington DC: American University, 2014.

\section{Websites:}

11Street. n.d. About 11Street. http://global.11st.co.kr/en/browsing/Eve 
181 Sukmawani Bela Pertiwi, Amalia Sustikarini, dan Paramitaningrum | The Impacts of E-Commerce to Regional Integration in Southeast Asia

ntPromotion.tmall? method=getEventPro motion\&dispObjNo=9885614. (accesed December 1,2017)

Aliexpress.Aliexpress.

https://www.aliexpress.com.(accessed December 1,2017)

Amazon, Alibaba Tussle in South-east Asia.

October 24.

http://www.straitstimes.com/business/a mazon-alibaba-tussle-in-south-east-asia. (accessed December 5, 2017)

ASEANup. 2017. Overview of e-commerce in Southeast Asia. November 8. https://aseanup.com/overview-of-ecommerce-in-southeast-asia/.(accesed December 5,2017)

Blibli. n.d. Tentang Blibli.com. https://www.blibli.com/panduanbelanja\#hash-sidetentangBlibli.(accesed December 5, 2017)

Bukalapak. n.d. Tentang Bukalapak. https://www.bukalapak.com/about. (accesed December 5, 2017)

Bydala. n.d. Bydala. http://bydala.com.(accesed December 8,2017)

Camhi, Jonathan. Southeast Asia's Set for Explosive E-Commerce Growth. May 16,2017 http://www.businessinsider.com/southea st-asias-set-for-explosive-e-commercegrowth-2017-5/?IR=T. (accesed December 8,2017)

CarsDB. n.d. CarsDB. https://www.carsdb.com/en.(accessed December 9, 2017)
Daraz. n.d. About Us. https://www.daraz.pk/about/.(accessed December 9,2017)

DHGate. n.d. DHGate. https://www.dhgate.com.(accessed December 9, 2017)

ebay. Our Company. https://www.ebayinc.com/ourcompany/.(accessed December 10,2017)

ecommerceiq.Indonesia. https://ecommerceiq.asia/topecommerce-sites-indonesia/.(accessed December 10,2017)

—. 2017. Malaysia. https://ecommerceiq.asia/topecommerce-sites-malaysia/.(accessed December 10,2017)

-. 2017. The Philippines. https://ecommerceiq.asia/topecommerce-sites-philippines/.(accessed December 10,2017)

—. 2017. Thailand. https://ecommerceiq.asia/topecommerce-sites-thailand/.(accessed December 10,2017)

-. 2017. Vietnam. https://ecommerceiq.asia/topecommerce-sites-vietnam/.(accessed December 10,2017)

Econsultancy. State of Ecommerce in Southeast Asia, 2014 https://econsultancy.com/reports/stateof-ecommerce-in-sea/. (accessed December 9, 2017)

Ezbuy. n.d. Ezbuy. https://ezbuy.sg.(accessed December 9, 2017) 
182 Sukmawani Bela Pertiwi, Amalia Sustikarini, dan Paramitaningrum | The Impacts of E-Commerce to Regional Integration in Southeast Asia

Freischland, Nadine. 2016. www.techinasia.com. 121. https://www.techinasia.com/openinglocal-office-ebay-catch-windindonesia.(accessed December 9,2017)

Gia, Vat. n.d. Vat Gia. https://www.vatgia.com/home/.(accesse d December 12,2017)

Glad Market. n.d. About Glad Market. http://www.gladmarket.com/about.html. (accessed December 12,2017)

Preqin, http://docs.preqin.com/reports/PreqinVenture-Capital-Southeast-AsiaSeptember-2016.pdf. August. (accessed December 5, 2017)

Shopee, https://help.shopee.com.my. (accessed December 12,2017) https://help.shopee.com.my/hc/enus/articles/115007181827-What-isShopee-Guarantee-How-does-it-work.(accessed December 12,2017)

n.d. https://liveatpc.com. Accessed 12 10, 2017. https://liveatpc.com/lazada-helps-smesgrow-everyonecansell/.(accessed December 12,2017)

iprice. iprice insights. June 2017 https://iprice.my/insights/mapofecomme rce/en/.(accessed December 15, 2017)

—. 2017. The Map of E-Commerce in Indonesia. June. https://iprice.co.id/insights/mapofecom merce/en/.(accessed December 12, 2017)

\section{—. 2017. The Map of E-Commerce in Thailand.} June. https://ipricethailand.com/insights/mapo fecommerce/en/.(accessed December $12,2017)$
—. 2017. The Map of E-Commerce in the Philippines. June. https://iprice.ph/insights/mapofecommer ce/.(accessed December 12, 2017)

—. 2017. The Map of E-Commerce in Vietnam. June.

https://iprice.vn/insights/mapofecommer ce/en/.(accessed December 12, 2017)

Khmer24.Khmer24. https://www.khmer24.com.(accessed December 9, 2017)

Kyat, One. One Kyat. https://www.onekyat.com.(accessed December 9, 2017)

Lazada. Lazada. http://lazada.co.id.(accessed December 9, 2017)

Lelong. Lelong. https://www.lelong.com.my.(accessed December 9, 2017)

\section{MAIO Mall.MAIO Mall.} http://www.maiomall.com.(accessed December 9, 2017)

Mall855. Mall855. http://www.mall855.com.(accessed December 9, 2017)

Marketeers Editor. Strategi Zalora Kembangkan Bisnis di Indonesia. September 27, 2015 http://marketeers.com/strategi-zalorakembangkan-bisnis-diindonesia/.(accessed December 12, 2017)

Maulana, Yosa. CEO Shopee: Kami Ingin Masyarakat Semakin Memahami ecommerce. February 13, 2017 https://swa.co.id/swa/ceo-interview/ceoshopee-kami-ingin-masyarakatsemakin-memahami-e- 
commerce.(accessed December 12, 2017)

MNL, Beauty.About Us. https://beautymnl.com/company. (accessed December 9, 2017)

NoteSPEC. NoteSPEC. https://notebookspec.com. (accesed December 10, 2017)

Qoo10. About Qoo10 \& Giosis. https://www.qoo10.com/gmkt.inc/Comp any/AboutCompany.aspx.(accessed December 9, 2017)

Sendo. Sendo. https://www.sendo.vn. (accessed December 5, 2017)

Shopee. Shopee. http://shopee.co.id.(accessed

December 5, 2017)

Shwe99. Shwe99. http://www.shwe99.com.(accessed December 5, 2017)

Tokopedia. About. https://www.tokopedia.com/about. (accessed December 12, 2017)

Yula.la. Yula.la. http://yula.la.(accessed December 9, 2017)

Zalora. About Zalora. https://www.zalora.com.my/about/. (accessed December 9, 2017)

Zwagyin Mart. About Us. http://www.zawgyimart.com/about. (accessed December 9, 2017) 